\title{
Theoretical frameworks in political ecology and participatory nature/forest conservation: the necessity for a heterodox approach and the critical moment
}

\author{
Mohammad Tanzimuddin Khan ${ }^{1}$ \\ University of Dhaka, Bangladesh
}

\section{Introduction}

Those theoretical frameworks of political ecology that have emerged from the Marxist tradition vary from one other depending on how particular scholars make use of the concept of power to interpret human/society/nature relations, and how they privilege one particular perspective over others. As a consequence, political ecology lacks a 'grand theory', a meta-narrative, or a comprehensive theoretical underpinning. Nonetheless, scholars are in agreement on a particular attribute of political ecology, that it is typically "power-laden rather than politically inert" (Biersack 2006: 5).

Taking advantage of this fluidity in theoretical approaches and the existing consensus on the 'powerladen' feature of political ecology, in this article I add a rather different twist, one that links humanity, society and nature. Rather than dealing with the issue of how power is manifested in human-environment relations, this article agues for introducing the concept of a critical moment in political ecology analysis. This concept is defined here as;

A conspicuous and sensitive moment that offers a specific insight into the interplay and autonomy of the actors involved in an event, one that illustrates or informs a political ecology analysis.

Attention to a critical moment and its aftermath helps reveal the multidimensional interpretations of power involving the actors and the event itself. Thus, I argue, it helps to progressively open up the institutional implications of the interplay of the actors involved in the nexus of human/society/nature. A focus on a critical moment does not examine 'power' from a theoretically predetermined position. A heterodox political ecology approach makes the analysis of an important moment more convincing and theoretically persuasive.

My analysis unfolds in the context of a current form of participatory development, popularly known as co-management based conservation. This is desirable because contemporary nature/forest conservation practice has led to the inclusion of a range of state and non-state actors (e.g., states, donor organisations, business organisations, NGOs, communities, academic institutes, think tanks etc.) in resource governance, making human-society-nature relations more complex and dynamic.

The categories of state and non-state actors who figure in these endeavours, however, are traditionally founded on their inherent functions without reflecting on the material interest(s) of each one (e.g., interests in natural/forest resource conservation, hydrocarbon resources). To make the concept of a critical moment a more appropriate analytical tool for political ecology, in the context of current participatory practices, state and non-state actors will need to be re-categorised as well. Hence, this article also proposes a set of new analytical categories: exogenous/shadow and endogenous.

The new categorisation of actors that I suggest takes into account the nature of actors' involvement and their material interests in nature/conservation projects. The term exogenous/shadow actor(s) refers to those that are not directly or formally involved, but still have a material stake in the nature/forest conservation site where they are in a common relationship with other actors falling within the endogenous category. The endogenous category describes those agents entrusted with the responsibility for implementing the nature/forest management project, with attendant conservation values. So these endogenous and exogenous actors are useful categories to capture the multiple agendas of a normative conservation project that may be acting as a backdrop or a trade-off for another resource extraction agenda. In such a scenario, the former is being used to justify the latter, or it is deployed to argue (in cost-benefit terms) the benefits as opposed to costs of a course of action.

\footnotetext{
${ }^{1}$ Mohammad Tanzimuddin Khan, Associate Professor, Department of International Relations, University of Dhaka, Bangladesh. E-mail: tanzim04 "at" gmail.com. I would like to express my sincere gratitude to the Journal of Political Ecology editor for wonderfully editing the article. This article is part of my recently completed PhD thesis, University of New England, Australia.
} 
My understanding of the term exogenous/shadow actor is a reversal of that of the 'shadow network', used by Bullock et al. (2012: 308-337). They deploy a 'shadow network' concept in analysing a comanagement based conservation project so as to imply a group which plays an indirect, but a pioneering role in formalising the collaboration efforts between state and non-state actors. In so doing, they focus only on the utilitarian aspects of this 'shadow network' involving the elements of social learning/knowledge and resilience of a community that are required for responding to a crisis.

In justifying the introduction of the notion of critical moment, the first section of this article briefly reflects on the major existing approaches to political ecology categorised in terms of neo-Marxist and postMarxist thought. The second section highlights the need for employing the critical moment as an analytical tool in combination with a heterodox political ecology approach for analysing participatory nature/forest conservation projects.

\section{Political ecology perspectives and their basic premises}

This section explores the basic premises of the neo-Marxist and post-Marxist approaches to political ecology, briefly pointing out the strengths and inadequacies of these approaches in dealing with the conservation of nature and forests.

\section{Neo-Marxist approaches}

Neo-Marxist approaches arose in opposition to apolitical neo-Malthusian views of human/society/nature complexities. Neo-Marxist approaches became popular for their simultaneous attention to political and economic factors in clarifying how material power (e.g. capital, wealth, military power) mediates human/society/nature relations (Biersack 2006: 3, 10; Bryant 1998: 80).

Neo-Malthusian views are based on an eco-scarcity argument originally put forward by Thomas Malthus. For him, an ecological 'crisis' erupts when the demands of a growing human population overtakes the capacity of an environmental system to support it. As a result, neo-Malthusian thinking emphasizes the need for population control to tackle ecological degradation, separating it from the issues concerning the global distribution of power and goods (Robbins 2004: 7-8). While much debated in populist movements for population stabilization and control, this view also finds an echo in a modernist approach to political ecology that focuses on efficiency-based idea of ecological risk mitigation.

Eric Wolf is often claimed to be the first to introduce the term political ecology, in 1972, although there were many precursors with small variations in meaning (for example, the critical social ecology of Peter Alexeivich Kropotkin; critical approaches of Alexender Humboldt, Elisee Reclus, Russel Wallace, Mary Fairfax Somerville, George Perkin Marsh; see Robbins 2004: 2-26 for details). Wolf reflected on cultural ecology, an approach associated with anthropologist Julian Steward, that assessed the degree to which small scale societies developed cultural attributes based upon material and environmental endowments and possibilities (Butzer 1989). Wolf also consulted orthodox Marxist texts, to develop his idea of political ecology. The drawback of cultural ecology lay, for him, in its emphasis on the "problematics of adaptation to the environment without attending to the structures of inequality that mediated human-nature articulations", while at the same time the obsessive concentration of orthodox Marxists on economic analysis served to neglect the importance of nature and environment (Biersack 2006: 3).

In later years, the political ecology approach has seen many twists and turns to stress the political economy, or the actions of political institutions, or the importance of environmental change itself in determining human-environment relationships (Biersack 2006: 3; see Robbins 2012: 14).

Marx himself, at least in the orthodox interpretation of his views, was preoccupied with issues of industrial progress and technological domination, so had tended to sideline nature altogether, or to see it simply in terms of the impact(s) of human exploitation (Biersack 2006: 35). But Foster (2011) disputes this assumption on the grounds that Marx in his very first political economic essay, Debates on the law on theft of wood (1842) had been attentive to ecological issues. Foster also points out that in Capital Marx introduced the concept of metabolic rift ${ }^{2}$, and seeks himself to deploy this concept in explaining ecological degradation under the impact of capitalist development (Foster et al. 2010; see Farahani 2013) Even if Foster had not been kind enough to point this out, it is certainly true that the point of departure for neo-Marxists is explaining the injustices of 'underdevelopment' and 'poverty', which - as political ecologists - they examine from a broader political economy framework, linking it with the issue of environmental change and the exploitation in terms of class, gender, or subaltern status (Bryant 2001: 152; Biersack 2006: 9).

Neo-Marxists also explain environmental change in the context of underdevelopment and poverty by deploying one of three major frameworks of thought: a core-periphery dependency analysis, global capitalist system/world system theory, and class inequality analysis. The global capitalist system, all argue, uses the

\footnotetext{
${ }^{2}$ The term metabolic rift is used to describe the state of the capitalist mode of production which results in the separation of humans from the natural environment from which they derive their sustenance, which in turn leads to its exploitation (Foster 1999: 380-381).
} 
'laws of capitalism' to guarantee profit, in turn leading to social and economic disparity, political and cultural oppression and the depletion of natural resources. ${ }^{3}$

Those who use a state-centric core-periphery framework, sometimes termed the 'dependency' model in its various iterations and forms, reflect on the lengthy structural subordination of third-world countries to the developed world through exchange relations, with perhaps less focus on the social relations of production underpinning those relations. There is also a class inequality approach, in which social relations of production receive priority. Here the emphasis is on profit accumulation by the capitalist class at the expense of the natural environment, natural resources, and other classes (Bryant 2001: 152-153). In this regard, Piers Blaikie, in The political economy of soil erosion in developing countries, argues that the capitalist class - in order to extract surpluses from peasants and pastoralists to increase profits - "...obliges land users to take out of the soil, pastures and forests what they cannot afford to put back in" ( Blaikie 1985: 7; see Biersack 2006: 11).

Apart from these three frameworks, a different approach called 'progressive contextualization' emerged in the 1980s. This approach links the environment with development issues by analysing the power of "non-place-based' forces' like transnational corporations over "place-based activities" involving agriculture and the like (Bryant 2001: 153). This approach, originally developed by Andrew Vayda (1983) requires sound anthropological knowledge of localities. Vayda, however, turned against his own work, later coauthoring 'Against political ecology' in 1999 because he then championed an inductive approach that did not necessarily privilege power (Vayda and Walters 1999).

The advantage of this wide collection of neo-Marxist approaches lies in their emphasis on global-local dimensions and linkages between a local community, such as a village in a developing country, and a nationstate, a region, and even the global market and institutions. They are relevant to investigating any contemporary natural resource conservation practices, since these inevitably cut across different spatial scales of analysis, at least when they have links to international institutions or markets (Biersack 1999: 10). For example, conservation projects currently being implemented in developing countries like the Nishorgo Support/IPAC project in Bangladesh (Khan 2010), cut across an exclusive concentration on the material aspect of power, leading in a measurable way to the establishment of anthropogenic domination over nature at the local scale and bringing local communities, nation-states and international donors together in an attempt to deliver nature conservation functions.

Where attention needs to be concentrated on structurally-deterministic production relations, for example where global actors aggressively appropriate natural resources that are already used to support local livelihoods, these neo-Marxist approaches help to explain surplus resource extraction by transnational companies. But there is a problem. For these theoretical approaches, while accepting the state as an agency of capital, overlooking the freedom it sometimes enjoys in relation to other institutional actors and in some forms means they can offer simplistic and monolithic accounts of the state's interests. More than this, the neo-Marxist concentration on the material aspect of power, culminating in the establishment of anthropogenic domination over nature, typically fails to shed light on the role of local politics as it involves actors at this scale, and gender and ethnic dimensions with regard to access to, and control over, resources (Bryant 1998: 82). Neo-Marxist frameworks are therefore criticised, on the grounds of their economic reductionism: i.e., for being too 'narrow' in vision, and overlooking other important non-material dimensions of power. While they have also been subject to changing intellectual fashions particularly since the 1980s, they may nonetheless produce a serious 'impasse' in understanding human/nature/social complexities (Bryant 1998: 154). This lacuna in neo-Marxist thought has recently given birth to a number of other approaches to political ecology analysis that have broadly been categorised as post-Marxist.

\section{Post-Marxist approaches}

Post-Marxist approaches to political ecology include feminist and post-structuralist perspectives. Elaboration rests on the premise that production relations are not merely embedded in capital; they are entrenched in "... a set of non-economic and non-capitalist relations" (Castree et al. 2001: 204). According to the thinkers working in this area, Marxist approaches also exaggerate "...production at the expenses of other processes cutting across gender, caste and ethnicity that simultaneously socialise nature" (ibid). To overcome these prevailing weaknesses, feminist scholars have examined power in terms of its gender dimensions, claiming that gender relations are pivotal for explaining human/society/nature relations and understanding the issue of access to, and control over, resources and their conservation. Following the work of historians like Sara Berry, they insist on the importance of the household in the scales used in political ecology analysis to explain outcomes (Rocheleau 2008: 722). When it comes to understanding the human/nature/society nexus, the feminist political ecology perspective takes into account the contexts of gendered knowledge, gendered

\footnotetext{
${ }^{3}$ Pioneering works in this regard include, Blaikie's Political economy of soil erosion (1985), Bunker's Underdeveloping the Amazon (1985), O'Brien's Sowing the seeds of famine (1985), Beresford and Fraser's 'Political economy of environment in Vietnam' (1992), Redclift's Development and the environment (1984), Harvey's 'The nature of environment' (1993), O'Connor's edited volume, Is capitalism sustainable? (1994) and many others.
} 
rights and responsibilities, and gendered politics and grassroots activism (Rocheleau et al. 1996: 3-5; Elmhirst 2011). ${ }^{4}$ It insists that gender differences are not biologically given, but ingrained in "...the social interpretation of biology and social constructs of gender..." (Rocheleau et al. 1996: 3). In short, the approach is inclusionary, urging the need for integrating and endorsing women as key actors (in the context of this article) in nature conservation programmes.

While feminist approaches bring a vital dimension to political ecology, one previously missing, they may still "... tend to reduce the presentation of social diversity to reified and stereotypical categories." (Forsyth 2003: 84). This can lead to an overly rigid analysis, akin to that economic reductionism to be found in more traditional neo-Marxist approaches. Under the impact of the emergence of post-structuralist approaches to power, subjectivity and women's agency, and because of their attention to the multidimensional subjectivities which mainstream the "de-centred subject" in analysing environment and gender relations, "...'gender' is destabilised as a central analytical category" (Elmhirst 2011: 130). Elmhirst suggests three specific feminist reformulations: conceptualising scales of analysis in terms of their interconnections; conceptualising embodiment in terms of material and emotional aspects; and conceptualising politics and subject construction of gender (ibid: 131). Still, Elmhirst's revision does not adequately explain how participatory practices may subordinate their environmental goals to the economic interest of the relevant endogenous and exogenous actors.

In the contemporary world, the establishment of more protected areas for the conservation of nature involving endogenous and exogenous actors is receiving greater global priority - against the backdrop of a constantly metamorphosing relationship between the values and practices of nature conservation and neoliberal capitalism (Vaccaro et al. 2013). For instance, in Laos, the World Bank was able to garner the support of the IUCN and the WWF in the construction of a series of ecologically harmful dams on the Mekong River, by setting up new alternative protected areas in the highlands for conserving watersheds and biodiversity, in which these two institutions were involved. The global conservation organizations IUCN and WWF initially opposed this 'offsetting' to permit a series of dam construction projects. The Bank had invested US $\$ 50$ billion to construct dams in the late 1990s, for energy production and its consumption by Laos and for commercial sale to neighbouring countries (Brockington et al. 2008: 3; Goldman 2001: 499523). In a similar fashion, Campo Maun and Mban et Djerem were declared as national parks in Cameroon so as to mitigate the damage caused by the World Bank funded Chad-Cameroon oil pipeline (Brockington et al. 2008: 4). These cases suggest that material interests - in this case the predicted returns on international loans, and the benefits of international energy projects for economic development prospects in poor nations - may induce the willing participation of endogenous and exogenous actors. These structural forces are hard to identify through a feminist political ecology focus on gender and access at local scales. Shewli (2008) in her work on the the USAID funded Nishorgo/IPAC Project in Bangladesh, examines womens' participation, their empowerment, and the impact of the project on their livelihood in the light of the declared objectives of the project. But she does not deploy a critical political ecology perspective, and overlooks the reasons that might have brought USAID and the Forest Department (FD) of Bangladesh together in launching this forest conservation project in the first place. In brief, what was at stake here was the fact that the site is located in a potential gas reserve zone where Chevron Bangladesh, a US-based transnational exploration company, is already operating (Khan 2010). In the case of a participatory co-management approach to forest conservation such as this, its embeddedness in larger socio-political realities raises questions that transcend gender issues and state borders.

Still, the emergence of post-structural approaches that focus on the 'non-material' dimensions of power has broadened the horizon of political ecology. Researchers utilising such approaches tend to analyse the formative role (as they see it) of the of 'agency-agenda-discourse' nexus in promoting certain forest/nature conservation practices or environmental projects in developing countries. ${ }^{5}$ In other words, human/society/nature interactions are analysed by signifying the role of discourse and the politics of the presentation of facts, thus de-emphasizing the material elements of nature conservation (e.g., those linked to capitalism). Relying on Foucault's 'discursive revolution', Escobar urges the need to understand nature as a 'social construction' wherein language is 'an active agent' (Escobar 1996, 1999; Bryant 2001: 162). With an exclusive focus on critical discourse analysis, there is a possibility of being led into semantics. But the power of the poststructural approach is when it leads us back to question of institutions, power and nature as is demonstrated when Escobar, citing Lakshman Yapa (1995: 1), writes:

Space, poverty and nature are seen through the lens of discursive materialism "where ideas, matter, discourse, and power are intertwined in ways that virtually defy dissection" (Escobar 1996a: 326).

\footnotetext{
${ }^{4}$ For example, Reed. and Mitchell (2003); Leach (2003) and Steinmann (1998).

${ }^{5}$ For example, Logan (2004); Leach and Mearns (1996); Woodhouse (2002); Bassett and Crummey (2003); Keeley and Scoones (2000); Bryant and Goodman (2004) and Fairhead and Leach (1998).
} 
When engaging politically with social movements, organisations and civil society, the post-structural strand of political ecology generates scepticism about the common/intersubjective meaning of concepts such as sustainable development, participation, and democracy. In the 1990s, it embraced a new vantage point, 'liberation ecology' which aims at "...the potentially liberatory or emancipatory potential of current political activity around environment and resources" (Peet and Watts 1996: 2-3; Forsyth 2001: 146). Liberation ecology was thought to be useful in analysing participatory nature conservation discourses, but some authors suffer from a strong tendency to underplay, or even fails to notice, the material factors (e.g. hydrocarbon resources) that seem to play a central role in forming the alliance between donors and environmental organisations. The root problem is that discourse analysis can downplay or ignore ethnographic material that reveals what is taking place on the ground. Unless combined with other methodologies, it fails to throw light on how the endogenous and exogenous mutually interact, and so it can overlook the gap between theoretical practice and ground reality.

This reality includes that fact that in many cases, international donors supporting conservation projects engage only those environmental NGOs that enjoy a common institutional relationship with relevant business enterprises in the guise of corporate social responsibility (CSR) - either globally, or nationally. This is as true for the Nishorgo/IPAC project in Bangladesh, as it is for the protected areas set up in the Mekong as discussed earlier.

Finally, because of their epistemological relativism, poststructuralists have been cautioned about playing into the hands of those pursuing anti-environmental political initiatives (Castree 1995: 38; Neumann 2005: 49). They have also been castigated for the "...risk of conflating their particular- but still valuableknowledges with truth", giving birth to an obvious question: "if nature is a social and discursive construction, why fight to preserve it?" (Soule 1995: 147; see also Castree 1995: 15; Neumann 2005: 49).

Neo-Gramscian and critical realist perspectives try to address those issues lacking in the existing 'explanatory-diagnostic' framework of Marxist or poststructuralist approaches (Castree 1995). The neoGramscian perspective contests the relevance of traditional Marxist 'historical materialism' to evaluate "...socio-environment dynamics and their functions", suggesting instead, the employment of "ethical materialism" (Mann 2009: 336). According to Mann, 'ethical materialism' emerges from the operation of 'hegemony' as it is entrenched in the "productive and ideological relations across social formations" (ibid: 340). It is undeniable that this perspective is valuable when it comes to analysing why and how hegemony is able to function in the "social life of thought- norms, morality, common sense". When it comes to the concerns of political ecology, it means, as Moore (2005: 23) says:

If landscapes are integrally entangled in power relations, then analysts need to take more seriously the environment and site-specific materialities enmeshed in rule, unequal resource distribution, and governmental projects.

It is an advantage of the neo-Gramscian approach that it addresses the micro-politics of natural resource governance in the context of a historicised state and a colonial setting (Mann 2009: 336; Paulson et al. 2003: 209). In a similar venture Horowitz (2012) has recently proposed a micro-political ecology using an actor-oriented ethnographic methodology.

Given the features of participatory conservation projects that have been recently advocated and implemented by donors around the world, the neo-Gramscian perspective helps to explain the connection between conservation and the interest of state actors over energy, minerals, and other valuable natural resources. The perspective highlights the hegemonic role of donors in association with civil society organisations, and with environmental NGOs. Still, such an analysis focuses only on the political aspects of the project without a strong focus on the ecological viewpoint and the politics of scientific knowledge into account. In short, it privileges politics over ecology and its analysis accepts scientific knowledge at face value (Bryant and Bailey 1997: 192; Forsyth 2001: 146; Nygren and Rikoon 2008: 770; Vayda and Walters 1999; Walker 2005).

The critical realist approach acknowledges one premise of the post-structural perspective - that nature, and the world, never come into fruition without mediation (Castree 1995: 38). Critical realists differ from their counterparts, however, because they argue nature and society can exist independently of any linguistic or conceptual imaginaries and intervention, since they believe that causal factors and structure survive independently of human perceptions (Castree 1995: 38; Peet and Watts 1996: 37; Patomaki and Wight 2000: 223; Roberts 1999: 21). They argue that because the poststructuralist framework gives primacy to local discourses and knowledge, it rationalises rather than critically assesses the way in which community participation in biodiversity or nature conservation projects operate hand in hand with neoliberal capitalism (Forsyth 2001: 147). 
Accordingly critical realists, under the influence of Roy Bhaskar's A realist theory of science (1997[1975]), tend to deal with scientific explanations of environmental change by asking how particular social and political relations influence the formation and use of apparent "apolitical scientific knowledge" (Forsyth 2001: 146-147; 2003: 20). Critical realists express their disagreement with traditional approaches to environmental science which ignore "the relationship between discourse, and the co-generation of so called "facts" and "norms"..." (Forsyth 2003: 3, 14). It follows that a truly critical political ecology must promote a political philosophy of environmental science that simultaneously unpacks how 'social and political framings' are entrenched in the formulation of scientific explanations of environmental problems, and goes on to propose solutions to deal with those problems (ibid: 1 ). The problem here is that at present the critical approach remains overly abstract by prioritising method over (specific particular) content(s) (Roberts 1999: 23). What we need, and what is needed, is a theory of praxis in Roberts' sense:

Praxis theory seeks to bridge the gap between 'abstract' and 'concrete' by suggesting that through practical activity humans reproduce the very structures which in turn produce them. 'Reality' can only be meaningful for human actors to the extent that they creatively come to know and understand it. Thus knowledge is generated through practical activity (Roberts 1999: 25).

\section{The relevance of a heterodox approach and the concept of a critical moment}

In this article I am not calling for a critical realist or poststructuralist re-assessment of 'scientific' knowledge or 'local' knowledge in order to understand and implement co-management and conservation practices based on a participatory approach. Nor do I reflect on the discourse of 'sustainable development', 'conservation', 'forest-degradation', or 'biodiversity' from those perspectives. Rather, and from a broader political ecology view, I argue that certain material interests may, and often do, provide exogenous actors with reasons to get involved with norm-driven endogenous actors, but not to ensure or further the avowed policy purpose of safeguarding natural/forest resources. In short, I take certain ecological concepts and placebased material interests as given, and investigate whether the 'dominant paradigm' of participatory forest conservation cutting across the interests of both endogenous and exogenous actors with their existing differentiation in terms of power is really for, or about, improving nature/forest conservation (Gillingham 2001: 803).

As we shall see when we look at certain contemporary participatory conservation schemes closely, they involve too many multi-dimensionalities and contradictions, ranging from the 'national interest' of state actors in conserving natural/forest resources and commercial profit of some business actors, to the globally popular norm of conserving forests for protecting biodiversity by ensuring the livelihood of local communities. In other words, they aim at producing some kind of win-win outcome with multiple benefits. Given these multi-dimensionalities and contradictory elements, it seems advisable for reasons of flexibility to adopt some kind of eclectic approach informed by those different theoretical approaches that we have considered.

Such an eclectic approach is adopted by Walker and Hurley (2004) in examining the failure of a collective natural resource management project implemented in Nevada County, California, USA. They look at the wider politics of collaboration by taking the power relationship among the participants of the Natural Heritage 2020 ( $\mathrm{NH} \mathrm{2020)}$ project as given. Assuming political ecology's broad focus on the 'constantly shifting dialectic between society and natural resources', Walker and Hurley (2004: 737-738) - without employing any particular theoretical perspective- concentrate on the 'practices and mechanism' of the institutional arrangement of the NH 2020 project. In doing so, they deploy the concepts of 'containment' and 'countercontainment'. They define containment as the "strategic management of public involvement in planning so as to minimize disruption to preconceived planning goals, typically through avoidance of conflict..., and control over knowledge and procedure" (Few 2001: 112). And they define 'countercontainment' in terms of 'capture', indicating control of the collaborative process by certain social groups for the realisation of the narrow interest of 'powerful economic actors.' According to Walker and Hurley, when such groups fail to capture the collaborative process, they tend to adopt 'derailment tactics' to 'delegitimate' it (Walker and Hurley 2004: 739).

Walker and Hurley then apply the notions of containment, counter-containment and derailment to demonstrate how the 'pro-growth' group and the 'environmentalist' group in their study led the NH 2020 project to its ultimate failure, because of the enmeshing of contradictory interests - these involved expanding residential and commercial development, and those trying to preserve the natural environment. Their flexibility in employing these concepts focused largely on the local dimensions of the endogenous actor's power struggle; they do not consider the interest(s) of those exogenous actors aligned with the pro-growth group or with the pro-conservation group. What were the material interest(s) that give birth to the development of these pro-conservation and pro-growth cohorts in California? These may be guessed from their stance on the issues, but Walker and Hurley do not reflect on the importance of material interest(s) that 
gives birth to the development of the pro-conservation or pro-growth cohort. Their attention was only on the local dimension of political competition over the collaborative project.

It is also undeniable that there exists a power asymmetry among the endogenous actors in the context of donor sponsored participatory projects in developing countries. This is particularly the case for donors and environmental organisations because of their financial capacity, supremacy in knowledge/discourse production, and their global image. Along with the existing power differential, the contradictory goals of forest conservation involving mining and forest management at times compel the participating actors to compromise their autonomy. Against this backdrop state actors, in most cases, by virtue of being the legitimate regulatory authority, take the lead in launching participatory conservation schemes in conjunction with the local community. It is rarely the other way round (the non-indigenous population in Peru sometimes embark on their own conservation projects on the basis of moral rationales that include nature's intrinsic values, religious or spiritual norms, desire for sustainability and an environmental concern for future generations; see Shanee 2013 for details). As a result, projects such as these remain embedded in a 'statenested system' wherein state actors remain in effective control of producing and ensuring legal rights in relation to natural resource conservation practice (Carlsson and Berkes 2005: 67). The Nishorgo/IPAC project in Bangladesh is no exception in this regard. In the case of this project, the donor, USAID, represents the US government, and the International Resources Group (IRG) is a contracted agent of the former, while the Forest Department implements the project on behalf of the Bangladesh government.

It is unequal power relations, and the physical characteristics of the natural resource/forest areas, seen in terms of conservation goals and prospective hydro-carbon resources or other resources, that create a 'politicised environment.' This involves the endogenous and the exogenous actors (Bryant 1998: 85). But this 'politicised environment' is epistemologically different from that of the three-dimensional environmental contexts offered by Bryant and Bailey (1997: 28) who distinguished an everyday dimension, an episodic dimension and a systemic dimension. Their 'everyday dimension' refers to humanly produced deforestation and salinisation; the 'episodic dimension' points to the periodic unequal human impact of 'natural disasters' (e.g., floods, storms etc.); and the 'systemic dimension' describes those physical changes produced by industrial activities (e.g., nuclear fallout, or the impact of pesticides on human consumption) (Bryant and Bailey 1997: 28-29). Bryant and Bailey's understanding of the 'politicised environment' on the basis of 'physical changes, the rate of impact, the political response and key concepts', confines itself to the analysis of environmental changes involving 'human-environment interaction' at different scales (ranging from local to global) that contributes to 'political and economic inequalities' (Bryant and Bailey 1997: 31-35). This has proven a useful starting-point for analyses since the 1990s, but it privileges the role of certain key actors (e.g., state, multilateral institutions, business organisations, environmental NGOs, and grass root actors) in understanding the global, regional and local processes of human/nature relations embedded in a global power structure (1997: 25). Their focus was only on third world developing countries, and how they are becoming subjects of such changes (hence third world political ecology). There is also the question of whether actors themselves hold competing interests, internally or over time. Environmental degradation is taking its toll everywhere and according to matters of degree, because of the presence of different politico-legal environmental protection frameworks and the maturity of the political system at the domestic level. In this regard, while evaluating the environmental impact of community based conservation projects in the Philippines, Brazil and the USA, Selfa and Wada reached the conclusion that:

...contested meanings of 'community; and 'conservation' are rooted in the politics of resource allocation.... In all three cases, broader 'communities of interest' have asserted resource claims often in opposition to geographic communities proximate to the resources (Selfa and Wada 2008: 961).

Within a 'politicised environment', I examine participatory forms of donor funded projects in which the politics of forest conservation are linked to the macro-interests of exogenous actors concerned with hydrocarbon resources and the biodiversity conservation in tropical rain forests. In fact, in the case of Nishorgo/IPAC in Bangladesh, this linkage between forest conservation and energy exploration is embedded in a participatory conservation framework wherein the endogenous actors, i.e., state actors, local community, and local NGOs are mutually interacting in the context of a common relationship with the endogenous actor (Chevron). Based on this linkage, one can focus on the state of forest conservation and reflect on the changes in the landscape of the forest area and its impact. The work of Bryant (1997), Guha (1989), and Peluso (1992) offer similar instances that shed light on the relationships not only between the state and the peasants but also among various state agents, political parties and rural populations to understand their interactions with nature.

To understand the 'power-laden' politicised environment, we need to consider the history of interactions within it. It is here that the critical moment is relevant since it exposes the interplay and autonomy of both endogenous and exogenous actors vis-a-vis the issue of natural resource management and underground resources (Khan 2010: 68). This moment comes into play when the endogenous and exogenous 
actors interact within or outside the formal framework of natural resource conservation in response to a dilemma stemming from the incompatible interests of conservation practice and business operations. In other settings, the critical moment may occur in relation to other environmental issues. Particular outcome(s) of any interaction have to be assessed from the broad network of actors' interests that bring them together; and from the intellectual framework of the relevant 'public transcripts' ${ }^{6}$ that are being produced to make 'the triumph of their partisa $n$ interests' 'natural' 'on a society-wide basis' (Bryant and Bailey 1997: 40; Escobar 1996; Peet and Watts 1996).

I should point out that the importance of critical moments has been elaborated elsewhere. Firstly, Fletcher (2010) insists on the importance of looking into interplay, while explaining how conservation discourse and practice are articulated within specific areas. But his use of the term 'interplay' is linked to Foucault's concept of 'governmentality' modified by Arun Agarwal (2005) to 'environmentality'. 'Environmentality' is defined as a 'general strategy of governing human action' in the realm of the environment (Fletcher 2010: 171-172). Fletcher advocates studying the interplay of different forms of environmentalities. Deploying Foucault's concepts of neoliberalism, discipline, sovereignty, and the 'art of government', he points to four types of environmentality: neoliberal, disciplinary, sovereign and truth, to discuss market-based-commodifying neoliberal conservation, ethical norm-based conservation, fortress conservation, and conservation based on deep ecological principles (Fletcher 2010: 175-178).

Secondly, while the poststructuralist approach to environmentality is well suited to look into the discursive factors involved in the interplay of different conservation frameworks, it puts the conservation practice of the actors representing state, market and society on the backburner; and as a result, it deemphasizes the material factors that cause the actors to give birth to such interplay in the first place. Contemporary participatory nature/forest conservation efforts coalesce at least two types of environmentality (e.g. neoliberal and disciplinary) as well as sovereign environmentality (e.g., where there is fortress conservation), and the art of government environmentality (e.g., deep ecology-based conservation). The last one is rare.

Thirdly, Vayda and Walters (1999: 167-170) pioneered their concept of event ecology, arguing that political ecology fails to reason from events. This event ecology is has a rather different focus than critical moments because they argue inductively for a wide range of possible influences on those events, determined through hybrid investigation and without recourse to any particular theoretical perspective (Penna-Firme 2013). Watts (2003; also see Walker 2005) calls their approach a parochial one on the pretext that they understand political ecology research only in terms of analysing biophysical events, largely disregarding knowledge and representation. Watts argues instead:

... [P]olitical ecology rests on the dialectical and non-linear relations between Nature and Society in which environment can be approached in a number of ways ... what political ecology has done obviously is to open up the category of the environment itself and explore its multiform representations ... Another way to approach the environment is to examine knowledge of the environment and why and how particular forms of knowledge predominate... (Watts 2003: 8-9).

The participatory conservation approach is aligned better with the concept of network governance, wherein state, and non-state actors ranging from local to global are reciprocally connected through actions and practices on the basis of a common normative framework of resource governance (Adger et al. 2001: 683). We can discern a further advantage of focusing on the critical moment, because it provides the analyst with a particular conjuncture that demands not only the examination of a particular interplay of the actors, but it also illuminates the conservation practices that follows from, or antedate, that episode.

I now turn to the issue of conservation practices, defined as "[that] by which we construct or administer the exploitation of resources" (Bakker 2007:434). Scholars researching environmental governance, attentive towards institutional and organisational transformations occurring under the influence of neoliberal reforms, argue that the field of political ecology would gain "from more robust ethnographic accounts of the complex and place-based sets of practices through which particular actors have produced, reproduced, and challenged these novel modes of governance - or, alternatively have failed to do so" (Himley 2008: 445). The imperative

\footnotetext{
${ }^{6}$ Bryant and Bailey (1997: 40) define public transcripts as "the socially accepted version of events represented in public documents, legal political ideologies, popular music and theatre, and so on." The term 'public transcript' comes from James Scott's work, Domination and the arts of resistance (1990).

${ }^{7}$ From a broader explanatory and sociological perspective, the interplay of the actors needs to be understood not in terms of a structure-agency dichotomy, but more in terms of Giddens' (1976) concept of 'structuration' that "treats structure (institutions) as both a product of and a constraint on human action" (Barley and Tolbert 1997: 97).
} 
of researching conservation practices has become more pressing because of the escalating global trend towards implementing the neoliberal participatory conservation approach.

In the case of Nishorgo/IPAC project in Bangladesh, the seismic survey of Chevron done at the Lawachhara National Park in Moulvibazar District in 2008-2009 was a critical moment as it pitted the endogenous actors, USAID-IRG-IUCN, the FD, and the local communities against the commercial operation of Chevron at a particular project site. Here, the contradictory demands of forest conservation and energy procurement clashed. This moment became ever more critical because the exogenous actors were bound together through a normative co-management framework of resource governance, while also having a financial relationship with some of the exogenous actors that implement the project-either in terms of corporate social responsibility, or in terms of commercial endeavour. The outcome of the actors' interplay, spinning off from the critical moment, and the endogenous actors' commitment to the normative goal of nature conservation depends on the institutional arrangements within which the actors are embedded. The institutional framework of donor-driven nature/forest conservation projects, for their operation, is based only on those conservation discourses that are promoted and made dominant by the organisations like the IUCN and WWF. These critical moments can also be found in the signing of strategic agreements by the International Union for Conservation of Nature with Shell, Holcim and TATA in 2007 to help with ecosystem management in Nigeria, whale conservation around the Shakhalin Island in Russia, formulating biodiversity conservation policy in Sri Lanka, Vietnam, and the conservation of turtles in east coast of India and Lesser Flamingo on the shores of Lake Natron of Tanzania (IUCN 2008: 51-52).

The notion of a critical moment provides a linkage between theory and practice. It accompanies the recategorisation of state and non-state actors into endogenous and exogenous actors, and critical moments are historical instances where these actors interact. These moments help political ecology uncover both structural and actor-oriented factors that provide a 'legitimate' foundation for co-management conservation.

In other words, critical moments are particularly relevant for analysing those donor funded, placebased participatory nature/forest conservation projects that are being implemented in the name of natureconservation benefits. And where the implementation process is designed to give an impression that the local populations are consenting and profiting, and where there is at least an exogenous actor, directly or indirectly operating in the area alongside any or all of the endogenous actor(s). The critical moment helps expose the nature of actors' participation, because nature/forest conservation projects move forward from certain instances to create a practical, operational network involving state, donors, private enterprise and communities. Such a network may be seen as transnational and indeed capitalist in the context of the current neoliberal order, operating with its own "hidden transcripts and extra-judicial arrangements that are not readily visible to outsiders" (Brockington et al. 2008: 91). The analysis of the critical moment invites the need for further research into the impact of such networks on the function of participatory projects, and indeed on the ecology of the declared goal of conservation. This is because operational reality may be very different from the stated goals. The extent of any gap between goal and reality is indicative of the extent to which the participating actors prioritize goals other than forest conservation.

\section{Concluding remarks}

This article begins with reflecting on theoretical fluidity that prevails in the existing political ecology frameworks. It has a twin aspiration: introduction of a tool termed as critical moment analysis in the context of a contemporary nature/forest conservation approach; and combining theory and practice together in political ecology research. For this I have redefined state- and non-state actors and named them exogenous and endogenous actors, and showed how they are linked in terms of their material interests (e.g. financing, mining, security of investment and trade). Notions like 'sustainable development', 'participatory resource governance', 'learning by doing', 'adaptive co-management' etc. dominate in offering a discursive foundation for neoliberal nature/forest conservation policy. But neo-Marxist and post-Marxist treatment of these discursive elements and material interests as separate, makes it strenuous to understand the inner dynamics of co-management nature/forest conservation and the institutional and ideological affinity between, and among, conservation organisations and business enterprises, including the multinational mining industries.

Neo-Marxist and post-Marxist analysts traditionally commence their analysis from a theoretically predetermined position. In place of this CMA provides an opportunity to decide on how to unconventionally combine the various potencies of the theoretical elements of neo-Marxism and post-Marxism in doing political ecology analysis, without rejecting them or privileging a particular perspective. For example, as discussed earlier, the strength of neo-Gramscian perspective lies in the fact that it can focus on the hegemonic role of the donors and the interests of state actors, environmental/conservation and civil society organisations for operating an environmental/conservation project. Similarly, critical realists agree with the post-structural perspective that environment/human interaction can also be understood by examining linguistic or conceptual imaginaries and interventions.

It is not an easy task to fuse two strong theoretical elements in political ecology research without fieldwork. Deployment of CMA can help a researcher to analyse a sensitive moment/event, significantly enhancing understanding of the actors and forces involved. The choice of CMA is critical. The researcher 
must reflect on the incongruous normative orientation of the endogenous and exogenous actors engaged in producing a particular critical moment. The seismic survey of Chevron done at the Lawachhara National Park in Moulvibazar District of Bangladesh in 2008-2009 was a critical moment because it juxtaposed the endogenous actors (USAID, IUCN, FD, subcontracted local NGOs, community leaders with the exogenous actor Chevron Bangladesh) and exposed the conflict between nature/forest conservation and capitalist profitability. The CMA approach can be effective in social science research on external donor financed projects where states, civil society organizations, NGOs, and business coalesce, despite their different and oppositional norms and orientations. The CMA assists in identifying who plays on whose ground, and whose interest(s) is dominant. It calls for a heterodox and investigative a posteriori approach, without $a$ priori rejection or acceptance of theoretical inclinations.

\section{References}

Adger, N.W., T.A. Benjaminsen, K. Brown and H. Svarstad. 2001. Advancing a political ecology of global environmental discourses. Development and Change 32: 681-715.

Agarwal, A. 2005. Environmentality: technologies of government and the making of subjects. Durham NC: Duke University Press.

Bakker, K. 2007. The commons versus the 'commodity': alter-globalization, anti-privatization and the human right to water in the global south. Antipode 39(3): 430-455.

Barley, S.R. and P.S. Tolbert. 1997. Institutionalization and structuration: studying the links between action and institution. Organization Studies 18(1): 93-117.

Bassett, T. and D. Crummey (eds.) 2003. African savannas: global narratives and local knowledge of environmental change. Oxford: James Currey.

Beresford, M. and L. Fraser 1992. Political economy of the environment in Vietnam. Journal of Contemporary Asia 22(1): 3-19.

Bhaskar, R. 1997 (1975). A realist theory of science. London: Verso.

Biersack, A. 1999. From the "new ecology" to the new ecologies. American Anthropologist 101(1): 5-18.

Biersack, A. 2006. Reimagining political ecology: culture/power/history/nature. In A. Biersack and J.B. Greenberg (eds.) Reimagining political ecology. Durham: Duke University Press. Pp. 3-40.

Blaikie, P.M. 1985. The political economy of soil erosion in developing countries. London: Longman.

Brockington, D. R. Duffy and J. Igoe 2008. Nature unbound conservation, capitalism and the future of protected areas. London: Earthscan.

Bryant, R.L. 1997. The political ecology of forestry in Burma. London: Hurst and Company.

Bryant, R.L. 1998. Power, knowledge and political ecology in the third world: a review. Progress in Physical Geography 22(1): 79-94.

Bryant, R.L. 2001. Political ecology: a critical agenda for change. In N. Castree and B. Braun (eds.) Social nature: theory, practice and politics. London: Blackwell. Pp. 151-169.

Bryant, R.L. and M.K. Goodman 2004. Consuming narratives; the political ecology of alternative consumption. Transactions of the Institute of British Geographers 9(3).

Bryant, R.L and S. Bailey 1997. Third world political ecology: an introduction. London: Routledge.

Bullock R., D. Armitage and B. Mitchell 2012. Shadow networks, social learning, and collaborating through crisis: building resilient forest-based communities in Northern Ontario, Canada. In B.E. Goldstein (ed.) Collaborative resilience: from crisis to opportunity. Boston: MIT Press. Pp. 309-337.

Bunker, S.G. 1985. Underdeveloping the Amazon: extraction, unequal exchange, and the failure of the modern state. Urbana: University of Chicago Press.

Butzer, K. 1989. Cultural ecology. In C.J. Wilmott and G.L. Gaile. Geography in America. New York: Merill.

Carlsson, L. and F. Berkes 2005. Co-management: concepts and methodological implications. Journal of Environmental Management 75: 65-76.

Castree, N. and B. Braun (eds.) 2001. Social nature: theory, practice and politics. Oxford and New York: Blackwell. $\underline{\text { Ch1 }}$

Castree, N. 1995. The nature of produced nature: materiality and knowledge construction in Marxism. Antipode 27(1): 12-48.

Elmhirst, R. 2011. Introducing new feminist political ecology. Geoforum 42: 129-132.

Escobar, A. 1996. Constructing nature: elements for a poststructural political ecology. In R.J. Peet and M.J. Watts (eds.) Liberation ecologies: environment, development, social movements. London: Routledge. Pp 46-68.

Escobar, A. 1996a. Constructing nature: elements for a poststructural political ecology. Futures 28(4): 325343. 
Escobar, A. 1999. After nature: steps to and antiessentialist political ecology. Current Anthropology 40(1): 130.

Farahani, I. 2013. Vanished in gaps, vanquished in rifts: the social ecology of urban spatial change in a working class residential area, Peykan-Shahr, Tehran, Iran. Journal of Political Ecology 20: 395-412.

Fairhead, J. and M. Leach 1998. Reframing deforestation: global analysis and local realities: studies in West Africa. London: Routledge.

Few, R. 2001. Containment and counter-containment: planner/community relations in conservation planning. Geographical Journal 167 (2): 111-124.

Fletcher, R. 2010. Neoliberal environmentality: towards a poststructuralist political ecology of the conservation debate. Conservation and Society 8(3): 171-181.

Forsyth, T.J. 2001. Critical realism and political ecology. In A. Stainer and G. Lopez (eds.) After postmodernism? London, UK: Athlone Press. Pp. 146-154.

Forsyth, T.J. 2003. Critical political ecology: the politics of environmental science. London, New York: Routledge.

Foster, J.B. 1999. Marx's theory of metabolic rift: classical foundations for environmental sociology. The American Journal of Sociology 105(2): 346-405.

Foster, J.B. 2011. The ecology of Marxian political economy. Monthly Review 63(4).

Foster, J.B., B. Clark, and R. York. 2010. The ecological rift: capitalism's war on the Earth. New York: Monthly Review Press.

Giddens, A. 1976. New rules of sociological method: a positive critique of interpretative sociologies. London: Hutchinson.

Gillingham, S. 2001. Social organization and participatory resource management in Brazilian rebeirinho communities: a case study of the Mamiraua Sustainable Development Reserve, Amazonas. Society and Natural Resources 14(9): 803-814.

Guha, R.C. 1989. The unquiet woods: ecological change and peasant resistance in the Himalaya. Delhi: Oxford University Press. (expanded, University of California Press, 2000)

Harvey, D. 1993. The nature of environment: the dialectics of social and environmental change. Socialist Register 29: 1-51.

Himley, M. 2008. Geographies of environmental governance: the nexus of nature and neoliberalism. Geography Compass 2(2): 433-451.

Horowitz, L.S. 2012. Power, profit, protest: grassroots resistance to industry in the global North. Capitalism Nature Socialism 23(3): 20-34.

IUCN 2008. Financial plan for the period 2009-2012. Congress paper CGR/2008/17. Gland: IUCN.

Keeley, J. I. Scoones 2000. Knowledge, power and politics: the environmental policy-making process in Ethiopia. The Journal of Modern African Studies 38(1): 89-120.

Khan, M.T. 2010. The Nishorgo Support Project, the Lawachara National Park, and the Chevron seismic survey: forest conservation or energy procurement in Bangladesh? Journal of Political Ecology 17: 68-78.

Khan, M.T. and T. Lynch 2013. The genealogy of contemporary nature/forest conservation. Human Geography: a New Radical Journal 6(3): 105-120.

Leach, M. 2003. Gender myths and feminist fables: repositioning gender in development policy and practice. A paper prepared for an international workshop orgnised by IDS, Sussex, held from 2-4 July.

Leach, M. and R. Mearns 1996. The lie of the land: challenging received wisdom on the African environment. Oxford: James Currey; Portsmouth, NH: Heinemann.

Logan, B.I. 2004. Ideology and power in resource management. In W. Moseley and B.I. Logan (eds.). African environment and development: rhetoric, programs, realities. Aldershot, Burlington, VT: Ashgate.

Mann, G. 2009. Should political ecology be Marxist? A case for Gramsci's historical materialism. Geoforum 40: 335-344.

Moore, D.S. 2005. Suffering for territory: race, place, and power in Zimbabwe. North Carolina: Duke University Press.

Neumann, R.P. 2005. Making political ecology. London, UK: Hodder Arnold.

Nygen, A. and S. Rikoon. 2008. Political ecology revisited: integration of politics and ecology does matter. Society and Natural Resources 21(9): 767-782.

O'Brien, J. 1985. Sowing the seeds of famine. Review of African Political Economy 33: 23-32.

O' Connors (ed.) 1994. Is capitalism sustainable? London, New York: Guilford Press. 
Patomaki, H. and C.Wight. 2000. After positivism? The promises of critical realism. International Studies Quarterly 44: 213-237.

Paulson, S., L.L. Gezon and M.J. Watts 2003. Locating the political in political ecology: an introduction. Human Organization 62(3): 205-217.

Peet, R.J. and M.J. Watts 1996. Liberation ecology: development, sustainability, and environment in an age of market triumphalism. In Peet R.J. and M.J. Watts (eds.) Liberation ecologies: environment, development, social movements. London: Routledge. Pp. 1-45.

Penna-Firme, R. 2013. Political and event ecology: critiques and opportunities for collaboration. Journal of Political Ecology 20:199-216.

Peluso, N. 1992. Rich forests, poor people: resource control and resistance in Java. Berkeley, CA: University of California Press.

Redclift, M. 1984. Development and the environmental crisis: red or green alternatives? London: Methuen.

Reed, M.G. and B. Mitchell 2003. Gendering environmental geography. The Canadian Geographer 43(3): 318-337.

Robbins, P. 2004. Political ecology: a critical introduction. Oxford: Blackwell.

Robbins, P. 2012. Political ecology: a critical introduction. Second edition. Oxford: Blackwell.

Roberts, J.M. 1999. Marxism and critical realism: the same, similar, or just plain different? Capital and Class 68: 21-29.

Rocheleau, D.E. 2008. Political ecology in the key of policy: from chains of explanation to webs of relations. Geoforum 39: 716-727.

Rocheleau, D.E., B. Thomas-Slayter, and E. Wangari 1996. Gender and environment. In Rocheleau, D.B. Thomas-Slayter, and E. Wangari (eds.) Feminist political ecology: global issues and local experiences. London: Routledge. Pp. 3-23. review

Scott, J.C. 1990. Domination and the arts of resistance: hidden transcripts. New Haven, CT; London: Yale University Press.

Selfa, T. and J. Endter-Wada 2008. The politics of community-based conservation in natural resource management: a focus for international comparative analysis. Environment and Planning A 40 (4): 948-965.

Shanee, N. 2013. Campesino justification for self-initiated conservation actions: a challenge to mainstream conservation. Journal of Political Ecology 20: 413-428.

Shewli, S.B. 2008. The role of women in co-management at Lawachara National Park. In J. Fox, B.R. Bushley, W.B. Miles and S.A. Quazi (eds.) Connecting communities and conservation: collaborative management of protected areas in Bangladesh. Honolulu, USA; Dhaka, Bangladesh: East-West Center and Nishorgo Support Project, Bangladesh Forest Department. Pp. 73-88.

Soule, M. 1995. The social siege of nature. In M. Soule and G. Lease (eds.) Reinventing nature? Responses to postmodern deconstruction. Washington, DC: Island Press. Pp. 137-170.

Steinmann, S. 1998. Gender, pastoralism and intensification: changing environmental resource use in Morocco. Yale Forestry and Environment Bulletin 103: 81-107.

Vaccaro, I., O. Beltran and P.A. Paquet 2013. Political ecology and conservation policies: some theoretical genealogies. Journal of Political Ecology 20: 255-272.

Vayda A.P. 1983 Progressive contextualization: methods for research in human ecology. Human Ecology II(3): 265-281.

Vayda, A.P. and B.B. Walters 1999. Against political ecology. Human Ecology 27(1): 167-179.

Walker, P.A. 2005. Political ecology: where is the ecology? Progress in Human Geography 29(1): $73-82$.

Walker, P.A. and P.T. Hurley. 2004. Collaboration derailed: the politics of "community-based" resource management in Nevada County. Society and Natural Resources 17: 735-751.

Watts, M.J. 2003. For political ecology. Unpublished manuscript. Berkeley: University of California.

Wolf, E. 1972. Ownership and political ecology. Anthropological Quarterly 45: 201-205.

Woodhouse, P. 2002. Natural resource management and chronic poverty in Sub-Saharan Africa: an overview. CRPC Working Paper No. 14. Chronic Poverty Research Centre, University of Manchester.

Yapa, L. 1995. Can postmodern discourse theory help alleviate poverty? Yes! Paper presented at the Annual meeting of the Association of American of Geographers, Chicago, 17 March. 


\begin{abstract}
In this paper I review the major theoretical approaches to political ecology, and then introduce a research tool. The critical moment is a noticeable historical instance or interaction. Given the fluidity in the theoretical frameworks of political ecology and the growing dominance of participatory discourse, exploring critical moments provides a foundation for a heterodox approach to explaining human/society/nature relations. It is a way to uncover the multidimensional interpretation of power involving environmental actors, struggles, and key events. One of the key research areas for political ecology is the conservation of nature and forest environments, and the use of the critical moment is explored in these.
\end{abstract}

Key words: Political ecology, critical moment analysis, conservation, Bangladesh

\title{
Résumé
}

Dans cet article, je vous propose un examen des principales approches théoriques de l'écologie politique, et ensuite présenter un outil de recherche. Le moment critique est une instance ou d'une interaction historique notable. Explorer les moments critiques fournit une base pour une approche hétérodoxe à expliquer les relations homme / société / nature. Ceci est utile dans le contexte de fluidité dans les cadres théoriques de l'écologie politique et la domination croissante du discours participatif. C'est une façon de découvrir l'interprétation multidimensionnelle du pouvoir impliquant des acteurs de l'environnement, des luttes et des événements clés. L'un des domaines clés de la recherche pour l'écologie politique est la conservation des milieux naturels et de la forêt, et l'utilisation de l'instant critique est explorée dans ce contexte.

Mots clés: écologie politique, analyse de moment critique, la conservation, le Bangladesh

\section{Resumen}

En este artículo reviso las principales aproximaciones teóricas a la ecología política, e introduzco una herramienta de investigación. El momento crítico es una instancia histórica notable o momento de interacción. Dada la fluidez en los marcos teóricos de la ecología política y el creciente dominio del discurso participativo, explorar momentos críticos provee la base de una aproximación heterodoxa para explicar las relaciones humano/sociedad/naturaleza. Esta es una forma de descubrir las interpretaciones multidimensionales de poder que envuelven actores ambientales, luchas, y momentos claves. Una de las áreas de investigación claves para la ecología política es la conservación de la naturaleza y de los bosques, y el uso del momento crítico es explorado en estas.

Palabras clave: política ecológica, análisis del momento crítico, proyectos de conservación, Bangladesh 